\title{
Differential Regulation of Ferritin Subunits and Iron Transport Proteins: An Effect of Targeted Hepatic X-Irradiation
}

\author{
Naila Naz, ${ }^{1,2}$ Shakil Ahmad, ${ }^{1}$ Silke Cameron, ${ }^{1}$ Federico Moriconi, ${ }^{1}$ Margret Rave-Fränk, ${ }^{2}$ \\ Hans Christiansen, ${ }^{2,3}$ Clemens Friedrich Hess, ${ }^{2}$ Giuliano Ramadori, ${ }^{1}$ and Ihtzaz A. Malik ${ }^{1}$ \\ ${ }^{1}$ Department of Gastroenterology and Endocrinology, University Medical Center, Georg-August University, Robert-Koch Straße 40, \\ 37075 Göttingen, Germany \\ ${ }^{2}$ Department of Radiation Therapy and Radiooncology, University Medical Center, Georg-August University, Robert-Koch-Straße 40, \\ 37075 Göttingen, Germany \\ ${ }^{3}$ Department of Radiation Oncology, Medizinische Hochschule Hannover, Carl-Neuberg Straße, 30625 Hannover, Germany
}

Correspondence should be addressed to Ihtzaz A. Malik; i.malik@med.uni-goettingen.de

Received 5 August 2013; Accepted 9 October 2013

Academic Editor: Brad Upham

Copyright (c) 2013 Naila Naz et al. This is an open access article distributed under the Creative Commons Attribution License, which permits unrestricted use, distribution, and reproduction in any medium, provided the original work is properly cited.

\begin{abstract}
The current study aimed to investigate radiation-induced regulation of iron proteins including ferritin subunits in rats. Rat livers were selectively irradiated in vivo at $25 \mathrm{~Gy}$. This dose can be used to model radiation effects to the liver without inducing overt radiation-induced liver disease. Sham-irradiated rats served as controls. Isolated hepatocytes were irradiated at 8 Gy. Ferritin light polypeptide (FTL) was detectable in the serum of sham-irradiated rats with an increase after irradiation. Liver irradiation increased hepatic protein expression of both ferritin subunits. A rather early increase ( $3 \mathrm{~h}$ ) was observed for hepatic TfR1 and Fpn-1 followed by a decrease at $12 \mathrm{~h}$. The increase in TfR 2 persisted over the observed time. Parallel to the elevation of AST levels, a significant increase $(24 \mathrm{~h})$ in hepatic iron content was measured. Complete blood count analysis showed a significant decrease in leukocyte number with an early increase in neutrophil granulocytes and a decrease in lymphocytes. In vitro, a significant increase in ferritin subunits at mRNA level was detected after irradiation which was further induced with a combination treatment of irradiation and acute phase cytokine. Irradiation can directly alter the expression of ferritin subunits and this response can be strongly influenced by radiation-induced proinflammatory cytokines. FTL can be used as a serum marker for early phase radiation-induced liver damage.
\end{abstract}

\section{Introduction}

Therapeutic radiation causes both acute and chronic toxicity in normal tissue [1]. Indeed, radiation-induced liver disease (RILD) is a serious clinical complication [2], due mainly to vessel damage. Radiation-induced inflammation is known to be mediated by cytokines [3] probably through activation of their transcription factors. These signalling cascades result in an increase in the plasma levels of a number of positive acute phase proteins (APPs) [4] and change in gene expression of several iron regulatory proteins $[3,5]$.

In the clinical setting, when radiation is applied to the entire liver, RT doses of 30 to 33 Gy carry a risk of about $5 \%$ of radiation-induced liver disease [6]. Most solid tumors require total RT doses of at least $60 \mathrm{~Gy}$ [7]. With the advent of stereotactically guided radiotherapy (SBRT), single dose radiation for hepatic metastases was possible with a medium dose of $24 \mathrm{~Gy}$; range 17-30 Gy [8]. For fractionated radiation of HCC, total dose of 24-60 Gy with daily doses of 2.3-2.5 Gy has been used $[9,10]$. Similar doses can be given to hepatic metastases [11]. With an increasing Child-Pugh score and decreasing liver function, total doses were reduced to $35 \mathrm{~Gy}$ in Child B patients [12]. Our model of $25 \mathrm{~Gy}$ single dose irradiation is a well-understood simplified model to study radiation-induced liver damage [3, 13-18]. It is minimally toxic at a high single dose. It can further be compared with other models of liver damage $[16,17,19]$. Studies on fractionated liver injury are on their way [20].

In the current study, we focused on the differential regulation of ferritin subunits under single dose $25 \mathrm{~Gy}$ liver irradiation. Iron is essential for metabolic processes. A large group of iron regulatory proteins controls iron homeostasis 
such as transferrin (Tf) [21], transferrin-receptors (TfRs) [22], and ferroportin-1 (Fpn-1) [23]. Within the cell, iron is mainly stored as ferritin [24]. In humans, ferritin is composed of two subunits: ferritin L and ferritin H. Both subunits are highly conserved [25], nevertheless, genetically separated [26, 27], and maintain distinct functions [28]. Both subunits are differentially and independently regulated on both, transcriptional and posttranscriptional level [28]. Serum ferritin levels are widely used in clinical settings and have become a part of the routine assessment of human body iron stores $[29,30]$. It has, however, become increasingly evident that several clinical conditions can be associated with elevated serum ferritin levels in the absence of iron overload $[28,31]$, while the identity of serum ferritin is not clear and its source is still a matter of debate [32].

The mechanism of iron uptake is partially known in other models but poorly understood in liver after irradiation. Single dose X-irradiation reduced the serum iron and can induce changes in hepatic expression of iron regulatory genes at mRNA level [3]. The aim of our prospective study is to extend the previous knowledge and monitor the changes at protein and mRNA level in hepatic iron transport (TfRs and Fpn-1) and storage (ferritin) proteins after targeted liver Xirradiation. Furthermore, we aimed to investigate the effect of $\mathrm{X}$-irradiation as regulator of ferritin subunits in the presence or absence of acute phase cytokines in isolated cultured hepatocytes.

\section{Methods}

2.1. Animal Model. A rat model for targeted liver $\mathrm{X}$ irradiation was established by CT planned single organ $\mathrm{X}$-irradiation as described before [3]. Rats were kept and sacrificed under standard conditions approved by institution's guidelines, as designated earlier [33]. Treated and shamirradiated controls were sacrificed at $1,3,6,12,24$, and $48 \mathrm{~h}$ after irradiation. Blood was collected to obtain serum. Liver tissues were taken carefully, rinsed with $0.9 \% \mathrm{NaCl}$, snap frozen in liquid nitrogen, and preserved at $-80^{\circ} \mathrm{C}$ for further use.

2.2. Isolation and Culture of Rat Hepatocytes. Hepatocytes were isolated from normal animals according to a protocol described previously [34]. The purity of the isolated cell population was determined by phase contrast microscopy and by immunocytochemistry using antibodies against laminin or GFAP to identify stellate cells (both from Sigma, Deisenhofen, Germany) or ED1 and ED2 (gift from C. Dijkstra) for macrophages. Dulbecco's modified Eagle's medium (DMEM) (Biochrom, Berlin, Germany) was supplemented with $10 \%$ fetal calf serum (FCS) (PAA, Cölbe, Germany), $1 \mathrm{nM}$ insulin (Roche, Mannheim, Germany), and $100 \mathrm{nM}$ dexamethasone (Sigma, Munich Germany). After isolation, the hepatocytes were either irradiated (8Gy) with $6 \mathrm{mV}$ Photons using Variance Clinac 600C accelerator [17] or irradiated and additionally exposed to $500 \mathrm{ng}$ of recombinant interleukin (IL) $1 \beta$, IL-6, or TNF- $\alpha$ (PeproTech, Rocky Hill, NJ) in $3 \mathrm{~mL}$ cell culture supernatants immediately before irradiation.
2.3. Preparation of Tissue Lysates for Total Protein Isolation and Western Blot Analysis. About $50 \mathrm{mg}$ of frozen tissue was homogenized with an Ultra-Turrax TP 18/10 three times for $10 \mathrm{~s}$ each. Lysis buffer contained $50 \mathrm{mM}$ Tris-HCl buffer ( $\mathrm{pH}$ 7.4), $150 \mathrm{mM}$ sodium chloride, $1 \mathrm{mM}$ ethylenediaminetetraacetic acid, 1\% Triton X-100, 1 mM phenylmethanesulfonyl fluoride, $1 \mathrm{mM}$ benzamidine, $1 \mathrm{mg} / \mathrm{mL}$ leupeptin, $10 \mathrm{mM}$ chymostatin, $1 \mathrm{mg} / \mathrm{mL}$ antipain, and $1 \mathrm{mg} / \mathrm{mL}$ pepstatin $\mathrm{A}$. The entire procedure was carried out at $4^{\circ} \mathrm{C}$. Crude homogenates were passed five times through a $22 \mathrm{G}$ needle attached to a syringe, centrifuged for $5 \mathrm{~min}$ at $10,000 \mathrm{~g}$ and $4^{\circ} \mathrm{C}$. The protein concentration was determined in supernatants using the Bradford protein assay reagent (Pierce, Germany). Aliquots of the homogenates were stored at $-20^{\circ} \mathrm{C}$ until further use for western blot analysis.

$50 \mu \mathrm{g}$ of protein from tissue and serum was applied per well for electrophoresis using NuPAGE-SDS-PAGE (4-12\% Bis-Tris Gel; Invitrogen, USA) under reducing conditions [35]. After electrophoresis; the proteins were transferred to Hybond-enhanced chemiluminescence (ECL) nitrocellulose membranes [36]. Western blot was performed utilizing FTL (Abcam and Santa Cruz) in 1:1000 and 1:100 dilution, respectively. FTH (Santa Cruz, Life Sciences Bio) in 1:100 and $1: 250$ dilution, respectively, TfR-1 (Invitrogen) in $1: 1000$ dilution, TfR-2 (Abcam) in 1:500 dilution, Fpn-1 (Proscience) in 1:500 dilution, $\beta$-actin (Sigma) in 1:4000 dilution. Immunodetection was performed utilizing ECL reagent.

2.4. RNA Isolation and Quantitative Real-Time PCR. Total RNA was isolated from cultured cells by means of guanidine isothiocyanate extraction, caesium chloride density-gradient ultracentrifugation, and ethanol precipitation according to a previously described method [37], with some modifications as described elsewhere [38]. The cDNA was generated by reverse transcription of $1 \mu \mathrm{g}$ of total RNA using $100 \mathrm{nM}$ of dNTPs, $50 \mathrm{pM}$ of primer oligo dT15, $200 \mathrm{U}$ of moloney murine leukaemia virus reverse transcriptase (M-MLV RT), $16 \mathrm{U}$ of protector RNase inhibitor in RT buffer, and $2.5 \mu \mathrm{L}$ of 0.1 M DTT; real-time PCR was performed using an ABI prism 7000 sequence detection system as described elsewhere [17]. The primer sequences used for RT-PCR are FTL 5-3 AACCACCTGACCAACCTCGCTA $5^{\prime}-3^{\prime}$ TCAGAGTGAGGCGCTCAAAGAG, FTH 5-3 GCC CTG AAG AAC TTT GCC AAAT, 5' - $3^{\prime}$ TGCAGGAAGATTCGTCCACCT, UBC53 CACCAAGAAGGTCAAACAGGAA $5^{\prime}-3^{\prime}$ AAGACACCTCCCCATCAAACC, and $\beta$-actin 5-3 TGT CAC CAA CTG GGA CGA TA $5^{\prime}-3^{\prime}$ AAC ACA GCC TGG ATG GCT AC. $\beta$-actin and ubiquitin $C$ were used as housekeeping genes. The results were normalized to the housekeeping gene and fold change expression was calculated using threshold cycle $\left(C_{t}\right)$ values.

2.5. Measurement of Circulating Aspartate Aminotransferase (AST) and Complete Blood Count (CBC). At time points ranging from 1 to 48 hours after targeted hepatic $\mathrm{X}$ irradiation, blood samples from the inferior vena cava were collected from sham-irradiated and irradiated rats and used for AST measurement using analysis kits (DiaSys, Germany) 
as instructed. The number of leukocytes in the blood of irradiated and sham-irradiated rats was determined by routine measurement.

2.6. Tissue Iron Level. Hepatic iron levels were measured utilizing a colorimetric ferrozine based assay [39]. To measure the iron concentration, tissue homogenates were prepared as reported previously [5].

2.7. Statistical Analysis. The data was analysed using Prism Graph pad 4 software (San Diego, USA). All experimental errors are shown as SEM. Statistical significance was calculated by one-way ANOVA and Dunnett post hoc test. Significance was accepted at $P<0.05$.

\section{Results}

3.1. Changes in Iron Storage and Transport Proteins in Serum and Liver after Irradiation. The protein amount of both, hepatic FTL and FTH was found to be elevated after single dose liver X-irradiation. By means of western blot FTL protein level was found to increase early $(3 \mathrm{~h})$ and remained above the control level until $24 \mathrm{~h}$, whereas hepatic FTH revealed a maximum increase at $6-12 \mathrm{~h}$ after liver irradiation (Figure 1(a)). An early ( $3 \mathrm{~h}$ ) and slight increase was detected in hepatic iron import (TfR1 and TfR2) and export proteins (Fpn-1). In contrast, a decrease in hepatic TfR1 and Fpn1 protein amount was evident at later time points. The minimum protein level of TfR1 was found at $12 \mathrm{~h}$ and for Fpn1 at $24 \mathrm{~h}$ after rat liver irradiation (Figure 1(a)).

A marked constitutive expression of FTL was detected in the serum of sham-irradiated controls and irradiated rats, while FTH was undetectable at any time point by Western blotting. Moreover, the serum protein level of FTL was found to increase early (3 h) after irradiation (Figure 1(b)).

3.2. Changes in Circulating AST and Hepatic Iron Level after Irradiation. Serum activity of AST was found to be elevated early after irradiation and reached a peak at $24 \mathrm{~h}$. This increase was found to be statistically significant (Figure 2(a)). An early decrease in iron level followed by a significant increase at $24 \mathrm{~h}$ was measureable in the liver tissue after irradiation as compared to the controls (Figure 2(b)).

3.3. Changes in Circulating Leukocyte Number after Irradiation. Complete blood count (CBC) analysis showed a decrease in total leukocyte count after liver irradiation. A rapid decrease $(1 \mathrm{~h})$ in total leukocytes number was observed with a minimum at $12 \mathrm{~h}$. The leukocyte count remained significantly lower than in sham-irradiated controls throughout the course of study (Figure 3(a)).

Differential CBC revealed that the major cell population, which was decreased after liver irradiation, was lymphocytes. A significant reduction was observed after $3 \mathrm{~h}$ with a minimum at $12 \mathrm{~h}$ (approx. 30\%) after irradiation. Furthermore, the numbers of lymphocytes remained below the control level until $48 \mathrm{~h}$. In contrast, a significant increase in neutrophils was detected with a maximum (1.82 \pm 0.13 -fold $)$ at

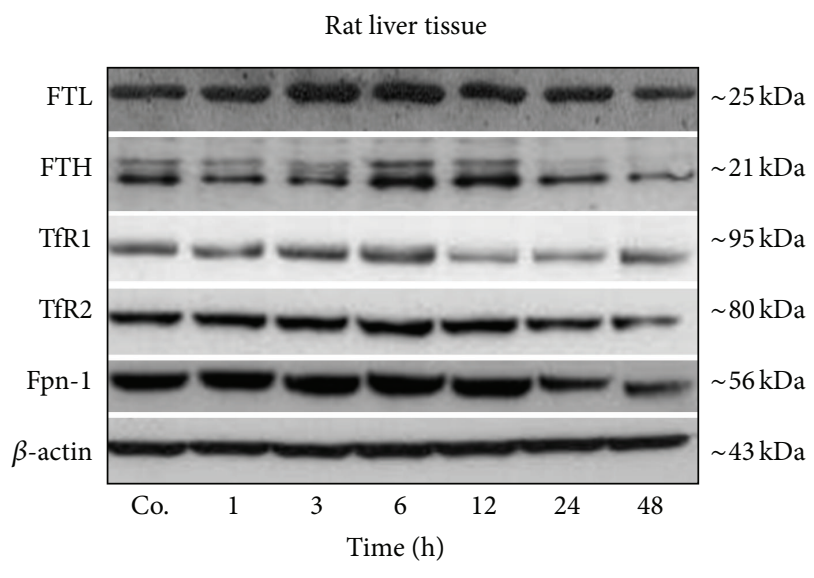

(a)

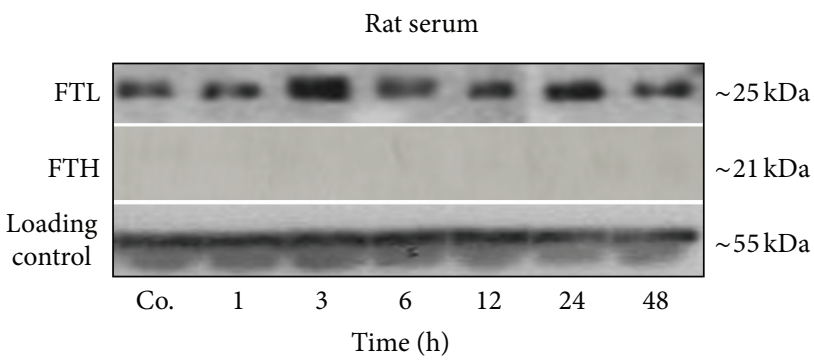

(b)

FIGURE 1: (a) Western blot analysis of iron storage (FTL and FTH) and iron transport protein (TfR1, TfR2 and Fpn-1) in rat liver of control and irradiated animals. (b) Western blot analysis of iron storage (FTL and FTH) proteins from serum total protein. $\beta$-actin was used as a loading control in liver while, in serum loading control represents an internal loading control $(\sim 55 \mathrm{kDa})$. Results are representative of three experiments.

$3 \mathrm{~h}$ (Figure 3(b)). However, no significant change in blood monocyte and erythrocyte (data no shown) number was found at any time after liver irradiation.

\subsection{Modulation of FTL and FTH Protein Gene Expression} in Isolated Rat Hepatocytes after Irradiation. FTL and FTH mRNA level in isolated rat hepatocytes significantly increased upon radiation exposure $(8 \mathrm{~Gy})$ alone or in combination with major acute phase cytokines (IL-1 $\beta$, IL-6, and TNF- $\alpha$ ) compared with untreated controls. Irradiation exposure of hepatocytes led to an increase in mRNA expression of both ferritin subunits throughout the study with a maximum at 6$12 \mathrm{~h}$. However, among the combination treatments, the most pronounced increase was observed after treatment with IL-6 and irradiation with a maximum at $12 \mathrm{~h}$. IL- $1 \beta$ had an early (1h) effect on FTL and FTH gene expression when combined with irradiation treatment (Figure 4).

\section{Discussion}

In this work, a brisk increase of FTL in the serum was detected after single dose liver irradiation. FTH, however, was not detected in the serum, neither of sham-irradiated controls 


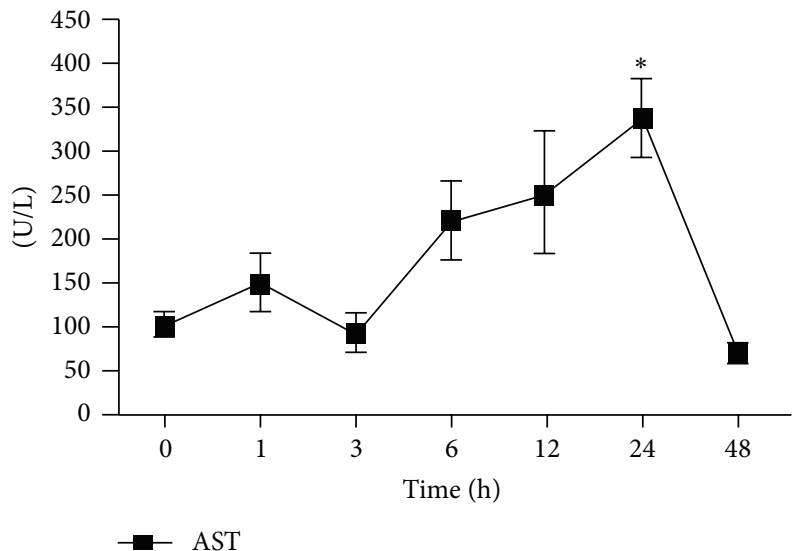

(a)

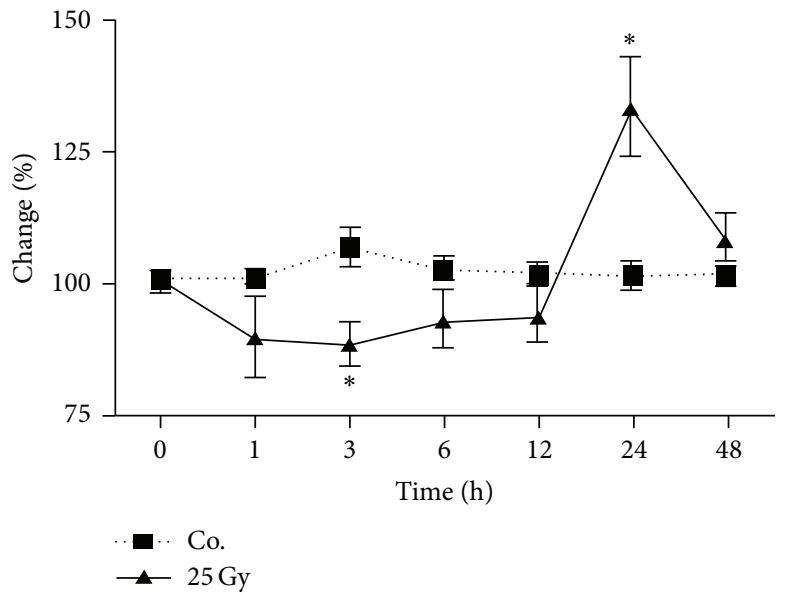

(b)

FIGURE 2: (a) Changes of circulating AST levels after targeted hepatic irradiation. (b) Changes in hepatic iron content after single dose liver irradiation. Iron levels were determined by ferrozine-based assay (Co. control). Results represent mean values \pm SEM ( ${ }^{*} P<0.05$ analyzed by one-way ANOVA; $n=3)$.

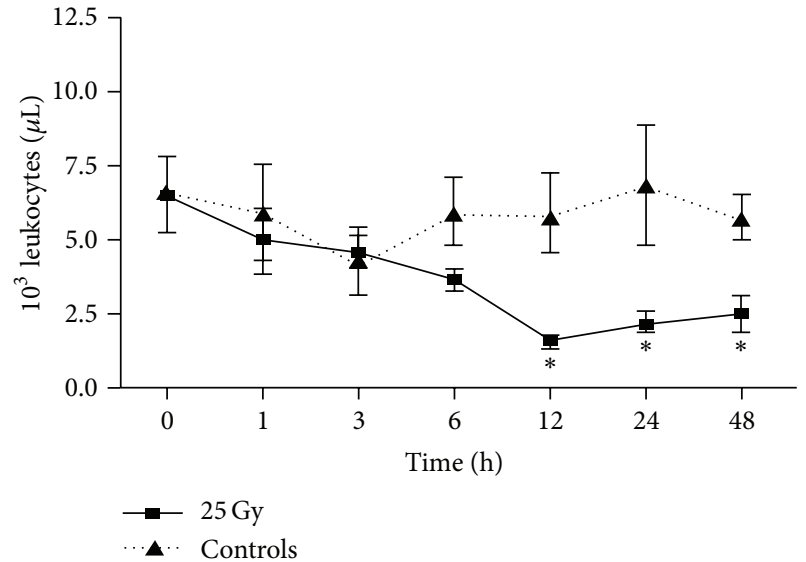

(a)

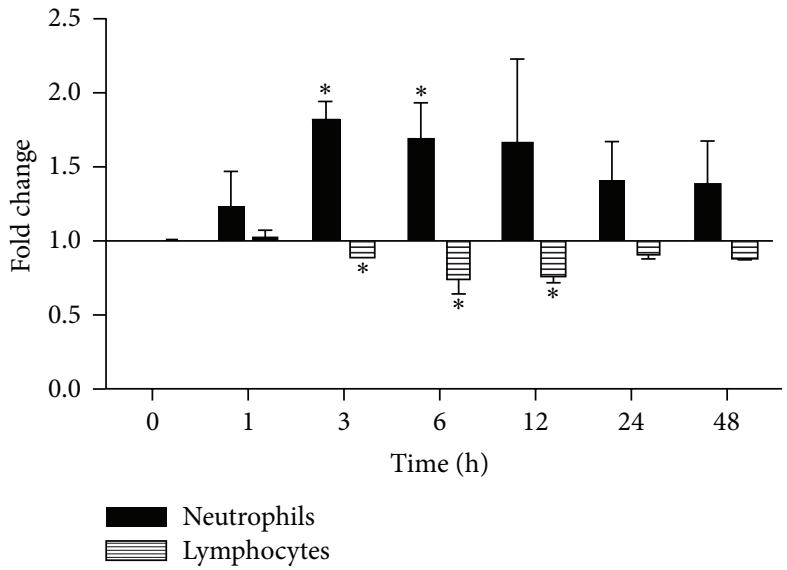

(b)

FIGURE 3: Changes in complete blood picture (CBC) after single dose liver irradiation. (a) Total leukocytes number. (b) Fold change in numbers of neutrophils and lymphocytes after targeted hepatic irradiation. Results represent mean values \pm SEM $\left({ }^{*} P<0.05\right.$ analyzed by one-way ANOVA; $n=3$ ).

nor of irradiated rats. In addition, hepatic protein expression of both genes was found to be elevated after irradiation. Similar to ferritin subunits, a mild early increase in iron import (TfR1 and TfR2) and iron export (Fpn-1) protein expression was observed, whereas an evident decrease in TfR1 and Fpn-1 at later time points $(24 \mathrm{~h})$ was found after irradiation.

Moreover, an increase in serum AST levels was detected in parallel to the increase in hepatic tissue iron levels. Complete blood count (CBC) analysis showed a significant decrease in leukocyte count over time, with an early increase in granulocyte count and a decrease in lymphocyte count after liver irradiation.

Ferritin is composed of two subunits: ferritin $\mathrm{L}$ and ferritin $\mathrm{H}$; however, previously ferritin was mostly studied as a single unit and role of its subunits was poorly described. Both subunits are highly conserved [25], nevertheless, genetically separated $[26,27]$, and maintain distinct functions [28]. Several observations reported that ferritin subunits (FTH and FTL) are iron storage proteins and their amount could only be modified by changes in iron status [40-42]. However, others and we reported that change in ferritinsubunits is not only due to the increase in hepatic iron concentration, but it could also be due to the direct effect of different inflammatory mediators such as acute-phase cytokines [33, 43-45]. Likewise our current study extended our previous knowledge where we showed an upregulation of proinflammatory cytokines in the same model [3] suggesting that a change in gene expression of ferritin subunits is also induced directly by irradiation or/and irradiation-induced 


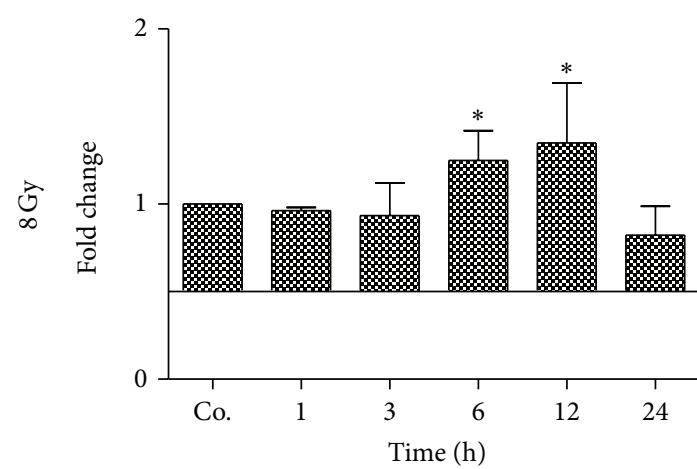

FTL

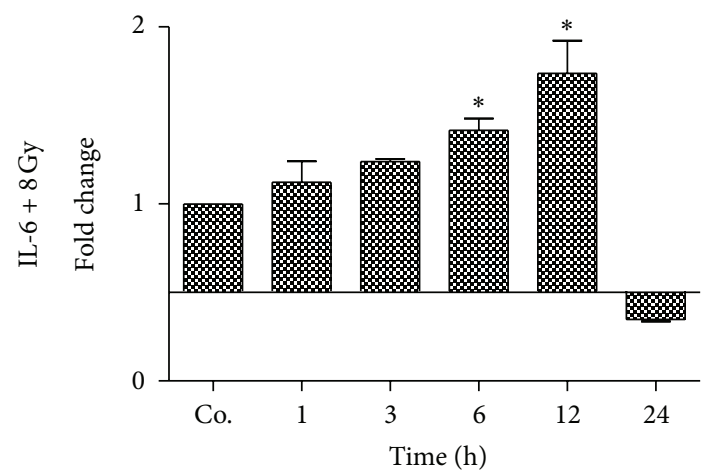

FTL

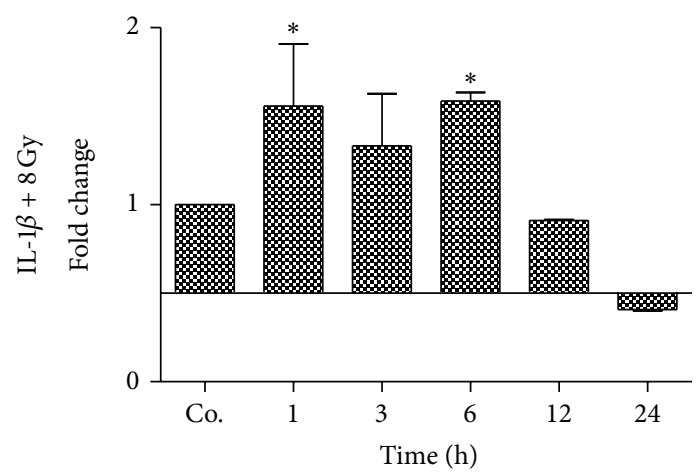

FTL

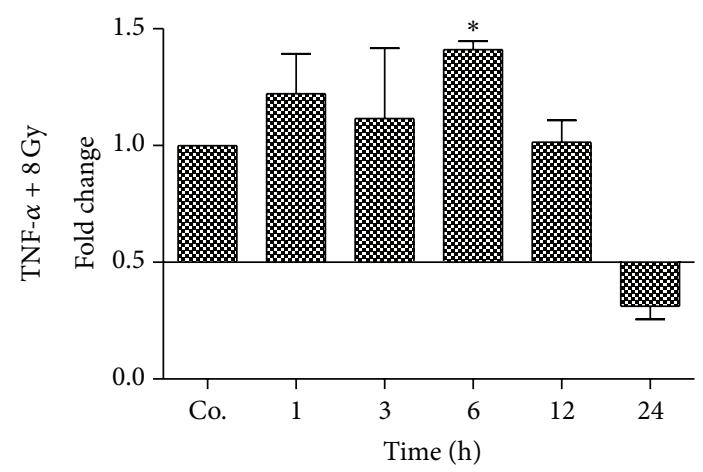

\% FTL

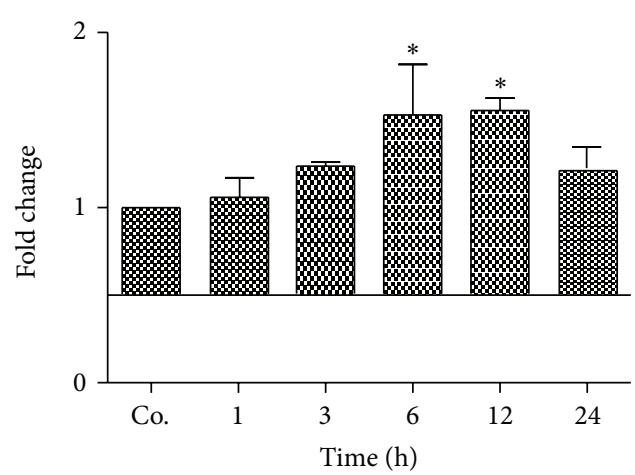

\% FTH

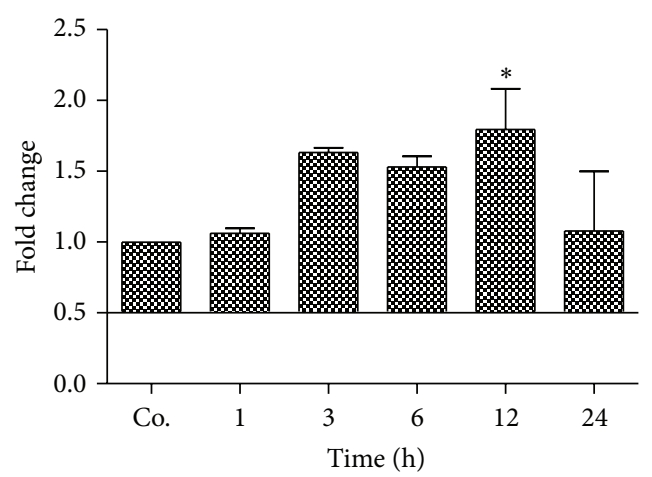

ॠ FTH

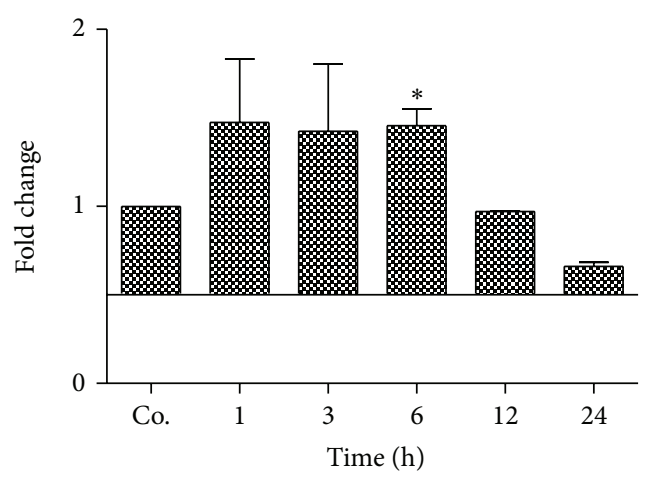

\% FTH

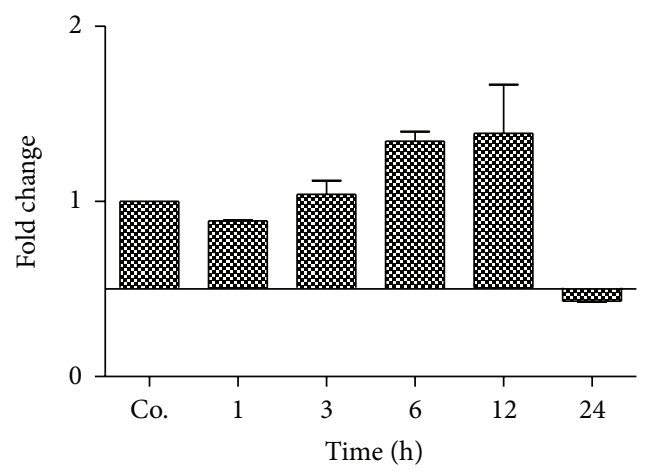

ฬ FTH

FIGURE 4: qRT-PCR analysis of total RNA from isolated rat hepatocytes treated with irradiation 8 Gy, alone or in combination with major acute phase cytokines (IL-6, IL-1 $\beta$ and TNF- $\alpha$ ). Data are shown as fold changes in mRNA expression of iron storage proteins (FTL and FTH) at various time points relative to untreated controls for each time point. qRT-PCR was normalized by using two housekeeping genes: $\beta$-actin and ubiquitin C. Results represent means \pm SEM of three experiments; ${ }^{*} P<0.05, n=3$. 
cytokines. In our current study, we showed changes in ferritin subunits induced directly by irradiation. This is an important aspect, as serum ferritin has been described as a risk factor for veno-occlusive disease [46]. It should, hence, be monitored under liver irradiation. In this context it has been shown that iron chelation may reduce the risk of hepatic veno-occlusive disease prior to high dose chemotherapy and auologous stem cell transplantation [47]. Moreover, hemostasis as well as cytokine and chemokine regulation is involved in venoocclusive liver disease [48]. Both these factors are affected by radiation treatment $[15,49,50]$. The current study supports these observations.

In addition, by using different detection methods (ELISA and western blot), we previously showed in different model that FTL serves as a secretory protein in a model of sterile abscess (acute phase response), where the liver responded to circulating acute phase cytokines produced at the site of injury [33]. Accordingly, in the current study, targeted hepatic X-irradiation resulted in a release of liver FTL into the serum. It indicates that FTL not only shares "the iron storage" function but also behaves as a secretory protein in the liver. This can also be true in the current study where an increase in serum FTL levels and hepatic FTL expression was observed after irradiation, suggesting that stress to the liver (in the present study caused by liver irradiation) induced hepatic FTL expression which could be responsible for an increase in serum FTL.

TfR1 is thought to be inversely regulated by the cellular iron status [51]. This is in accordance with our findings in rat liver after X-irradiation. An increase in the iron import proteins and later reduced expression of the iron export protein Fpn-1-in parallel to increased hepatic iron levelscould suggest a transient iron retention within the hepatocyte to fulfil the requirements of damage or stress conditions (increased AST level) caused by irradiation.

Another aspect of the current study was the observation of leucopenia mainly with low lymphocyte numbers after irradiation. This could explain the only mild inflammation with marginal hepatic increase in neutrophil granulocytes in our model [17]. Radiation could have reduced the number of leukocytes available for mounting an inflammation. A link between lower iron levels and decrease in leukocyte number have already been described $[52,53]$. A study showed a lower lymphocyte number in patients with iron deficiency anemia (IDA) which could also be true in our studied model [52].

Clinically, regulation of iron metabolism could be an underestimated response in radiotherapy. Further understanding of iron metabolism before and during radiotherapy could help to understand irradiation-induced hepatocellular damage/fibrosis and the impact of reduced iron levels on immune responses in patients with iron deficiency anemia. A strong correlation between radiation-induced cytokines and iron regulatory proteins has been found in patients with prostate cancer after radiotherapy [14]. However, further prospective clinical studies need to be performed to correlate iron metabolism dynamics with the clinical course of patients developing irradiation-induced problems. This would help to understand whether a change in iron or iron regulatory proteins could predict onset of symptoms.
Taken together, our data suggest that ferritin subunits are influenced not only by the iron status but also by cytokines as well as irradiation directly. This hypothesis was further confirmed by our in vitro experiments (isolated cultured hepatocytes) where a differentially regulated expression of ferritin subunits was found in hepatocytes after exposure to irradiation together with cytokines. Furthermore, FTL can be a potential biomarker for early phase radiation-induced liver damage.

\section{Conflict of Interests}

The authors have no conflict of interests regarding the publication of this paper.

\section{Acknowledgments}

The authors thank Mrs. S. Zachmann and Mrs. D. Gerke for their kind and skilful technical assistance. This work has been supported by DFG Grant (Project no. MA-5488/2-1).

\section{References}

[1] D. Citrin, A. P. Cotrim, F. Hyodo, B. J. Baum, M. C. Krishna, and J. B. Mitchell, "Radioprotectors and mitigators of radiationinduced normal tissue injury," Oncologist, vol. 15, no. 4, pp. 360371,2010

[2] S. J. Shim, J. Seong, I. J. Lee, K. H. Han, C. Y. Chon, and S. H. Ahn, "Radiation-induced hepatic toxicity after radiotherapy combined with chemotherapy for hepatocellular carcinoma," Hepatology Research, vol. 37, no. 11, pp. 906-913, 2007.

[3] H. Christiansen, N. Sheikh, B. Saile et al., "X-irradiation in rat liver: consequent upregulation of hepcidin and downregulation of hemojuvelin and ferroportin-1 gene expression," Radiology, vol. 242, no. 1, pp. 189-197, 2007.

[4] G. Ramadori and B. Christ, "Cytokines and the hepatic acutephase response," Seminars in Liver Disease, vol. 19, no. 2, pp. 141$156,1999$.

[5] N. Sheikh, J. Dudas, and G. Ramadori, "Changes of gene expression of iron regulatory proteins during turpentine oil-induced acute-phase response in the rat," Laboratory Investigation, vol. 87, no. 7, pp. 713-725, 2007.

[6] B. Emami, J. Lyman, A. Brown et al., "Tolerance of normal tissue to therapeutic irradiation," International Journal of Radiation Oncology Biology Physics, vol. 21, no. 1, pp. 109-122, 1991.

[7] B. B. Borgelt, R. Gelber, and L. W. Brady, "The palliation of hepatic metastases: results of the radiation therapy oncology group pilot study," International Journal of Radiation Oncology Biology Physics, vol. 7, no. 5, pp. 587-591, 1981.

[8] D. Habermehl, K. K. Herfarth, J. L. Bermejo et al., "Single-dose radiosurgical treatment for hepatic metastases-therapeutic outcome of 138 treated lesions from a single institution," Radiation Oncology, vol. 8, article 175, 2013.

[9] A. Bujold, C. A. Massey, J. J. Kim et al., "Sequential phase I and II trials of stereotactic body radiotherapy for locally advanced hepatocellular carcinoma," Journal of Clinical Oncology, vol. 31, pp. 1631-1639, 2013.

[10] M. Kong, S. E. Hong, W. S. Choi, J. Choi, and Y. Kim, “Treatment outcomes of helical intensity-modulated radiotherapy for 
unresectable hepatocellular carcinoma," Gut and Liver, vol. 7, pp. 343-351, 2013.

[11] A. Lausch, K. Sinclair, M. Lock et al., "Determination and comparison of radiotherapy dose responses for hepatocellular carcinoma and metastatic colorectal liver tumours," British Journal of Radiology, vol. 86, no. 1027, Article ID 20130147, 2013.

[12] N. Sanuki, A. Takeda, Y. Oku et al., "Stereotactic body radiotherapy for small hepatocellular carcinoma: a retrospective outcome analysis in 185 patients," Acta Oncologica, 2013.

[13] S. Cameron, A. Schwartz, S. Sultan et al., "Radiation-induced damage in different segments of the rat intestine after external beam irradiation of the liver," Experimental and Molecular Pathology, vol. 92, no. 2, pp. 243-258, 2012.

[14] H. Christiansen, B. Saile, R. M. Hermann et al., "Increase of hepcidin plasma and urine levels is associated with acute proctitis and changes in hemoglobin levels in primary radiotherapy for prostate cancer," Journal of Cancer Research and Clinical Oncology, vol. 133, no. 5, pp. 297-304, 2007.

[15] F. Moriconi, H. Christiansen, D. Raddatz et al., "Effect of radiation on gene expression of rat liver chemokines: in vivo and in vitro studies," Radiation Research, vol. 169, no. 2, pp. 162$169,2008$.

[16] F. Moriconi, I. Malik, G. Ahmad et al., "Effect of irradiation on gene expression of rat liver adhesion molecules: in vivo and in vitro studies," Strahlentherapie und Onkologie, vol. 185, no. 7, pp. 460-468, 2009.

[17] I. A. Malik, F. Moriconi, N. Sheikh et al., "Single-dose gammairradiation induces up-regulation of chemokine gene expression and recruitment of granulocytes into the portal area but not into other regions of rat hepatic tissue," The American Journal of Pathology, vol. 176, no. 4, pp. 1801-1815, 2010.

[18] S. Sultan, S. Cameron, S. Ahmad et al., "Serum Lipocalin2 is a potential biomarker of liver irradiation damage," Liver International, vol. 33, pp. 459-468, 2013.

[19] G. Ahmad, G. Z. K. Sial, P. Ramadori, J. Dudas, D. S. Batusic, and G. Ramadori, "Changes of hepatic lactoferrin gene expression in two mouse models of the acute phase reaction," International Journal of Biochemistry and Cell Biology, vol. 43, no. 12, pp. 18221832, 2011.

[20] M. Rave-Frank, I. A. Malik, H. Christiansen et al., "Rat model of fractionated (2 Gy/day) 60 Gy irradiation of the liver: longterm effects," Radiation and Environmental Biophysics, vol. 52, pp. 321-338, 2013.

[21] E. H. Morgan, "Specificity of hepatic iron uptake from plasma transferrin in the rat," Comparative Biochemistry and Physiology A, vol. 99, no. 1-2, pp. 91-95, 1991.

[22] E. H. Morgan and E. Baker, "Role of transferrin receptors and endocytosis in iron uptake by hepatic and erythroid cells," Annals of the New York Academy of Sciences, vol. 526, pp. 6582, 1988.

[23] A. T. McKie, P. Marciani, A. Rolfs et al., "A novel duodenal iron-regulated transporter, IREG1, implicated in the basolateral transfer of iron to the circulation," Molecular Cell, vol. 5, no. 2, pp. 299-309, 2000.

[24] T. Ganz and E. Nemeth, "Iron metabolism: interactions with normal and disordered erythropoiesis," Cold Spring Harbor Perspectives in Medicine, vol. 2, no. 5, Article ID a011668, 2012.

[25] P. Arosio, R. Ingrassia, and P. Cavadini, "Ferritins: a family of molecules for iron storage, antioxidation and more," Biochimica et Biophysica Acta, vol. 1790, no. 7, pp. 589-599, 2009.
[26] J. H. Caskey, C. Jones, Y. E. Miller, and P. A. Seligman, "Human ferritin gene is assigned to chromosome 19," Proceedings of the National Academy of Sciences of the United States of America, vol. 80, no. 2, pp. 482-486, 1983.

[27] M. Worwood, J. D. Brook, S. J. Cragg et al., "Assignment of human ferritin genes to chromosomes 11 and 19q13.3 $\rightarrow$ 19qter," Human Genetics, vol. 69, no. 4, pp. 371-374, 1985.

[28] M. C. Sammarco, S. Ditch, A. Banerjee, and E. Grabczyk, "Ferritin $\mathrm{L}$ and $\mathrm{H}$ subunits are differentially regulated on a posttranscriptional level," Journal of Biological Chemistry, vol. 283, no. 8, pp. 4578-4587, 2008.

[29] W. Wang, M. A. Knovich, L. G. Coffman, F. M. Torti, and S. V. Torti, "Serum ferritin: past, present and future," Biochimica et Biophysica Acta, vol. 1800, no. 8, pp. 760-769, 2010.

[30] M. Worwood, "Serum ferritin," CRC Critical Reviews in Clinical Laboratory Sciences, vol. 10, no. 2, pp. 171-204, 1979.

[31] A. Cozzi, B. Corsi, S. Levi, P. Santambrogio, G. Biasiotto, and P. Arosio, "Analysis of the biologic functions of $\mathrm{H}$ - and L-ferritins in HeLa cells by transfection with siRNAs and cDNAs: evidence for a proliferative role of L-ferritin," Blood, vol. 103, no. 6, pp. 2377-2383, 2004.

[32] L. A. Cohen, L. Gutierrez, A. Weiss et al., "Serum ferritin is derived primarily from macrophages through a nonclassical secretory pathway," Blood, vol. 116, no. 9, pp. 1574-1584, 2010.

[33] N. Naz, F. Moriconi, S. Ahmad et al., "Ferritin L is the sole serum ferritin constituent and a positive hepatic acute phase protein," Shock, vol. 39, no. 6, pp. 520-526, 2013.

[34] G. Ramadori, U. Moebius, H.-P. Dienes, S. Meuer, and K.H. Meyer Zum Buschenfelde, "Lymphocytes from hepatic inflammatory infiltrate kill rat hepatocytes in primary culture. Comparison with peripheral blood lymphocytes," Virchows Archiv B, vol. 59, no. 5, pp. 263-270, 1990.

[35] U. K. Laemmli, "Cleavage of structural proteins during the assembly of the head of bacteriophage T4," Nature, vol. 227, no. 5259, pp. 680-685, 1970.

[36] H. Towbin, T. Staehelin, and J. Gordon, "Electrophoretic transfer of proteins from polyacrylamide gels to nitrocellulose sheets: procedure and some applications," Proceedings of the National Academy of Sciences of the United States of America, vol. 76, no. 9, pp. 4350-4354, 1979.

[37] J. M. Chirgwin, A. E. Przybyla, R. J. MacDonald, and W. J. Rutter, "Isolation of biologically active ribonucleic acid from sources enriched in ribonuclease," Biochemistry, vol. 18, no. 24, pp. 5294-5299, 1979.

[38] G. Ramadori, J. D. Sipe, and C. A. Dinarello, "Pretranslational modulation of acute phase hepatic protein synthesis by murine recombinant interleukin 1 (IL-1) and purified human IL-1," Journal of Experimental Medicine, vol. 162, no. 3, pp. 930-942, 1985.

[39] J. Riemer, H. H. Hoepken, H. Czerwinska, S. R. Robinson, and R. Dringen, "Colorimetric ferrozine-based assay for the quantitation of iron in cultured cells," Analytical Biochemistry, vol. 331, no. 2, pp. 370-375, 2004.

[40] C. Beaumont, P. Leneuve, I. Devaux et al., "Mutation in the iron responsive element of the $\mathrm{L}$ ferritin mRNA in a family with dominant hyperferritinaemia and cataract," Nature Genetics, vol. 11, no. 4, pp. 444-446, 1995.

[41] D. Darshan, L. Vanoaica, L. Richman, F. Beermann, and L. C. Kühn, "Conditional deletion of ferritin $\mathrm{H}$ in mice induces loss of iron storage and liver damage," Hepatology, vol. 50, no. 3, pp. 852-860, 2009. 
[42] E. G. Meyron-Holtz, S. Moshe-Belizowski, and L. A. Cohen, "A possible role for secreted ferritin in tissue iron distribution," Journal of Neural Transmission, vol. 118, no. 3, pp. 337-347, 2011.

[43] N. Sheikh, D. S. Batusic, J. Dudas et al., "Hepcidin and hemojuvelin gene expression in rat liver damage: in vivo and in vitro studies," The American Journal of Physiology-Gastrointestinal and Liver Physiology, vol. 291, no. 3, pp. G482-G490, 2006.

[44] J. Muntane-Relat, J.-C. Ourlin, J. Domergue, and P. Maurel, "Differential effects of cytokines on the inducible expression of CYP1A1, CYP1A2, and CYP3A4 in human hepatocytes in primary culture," Hepatology, vol. 22, no. 4, pp. 1143-1153, 1995.

[45] S. V. Torti, E. L. Kwak, S. C. Miller et al., "The molecular cloning and characterization of murine ferritin heavy chain, a tumor necrosis factor-inducible gene," Journal of Biological Chemistry, vol. 263, no. 25, pp. 12638-12644, 1988.

[46] M. Morado, E. Ojeda, J. Garcia-Bustos et al., "Serum ferritin as risk factor for veno-occlusive disease of the liver. Prospective cohort study," Hematology, vol. 4, no. 6, pp. 505-512, 2000.

[47] H. W. Chueh, K. W. Sung, S. H. Lee et al., "Iron chelation treatment with deferasirox prior to high-dose chemotherapy and autologous stem cell transplantation may reduce the risk of hepatic veno-occlusive disease in children with high-risk solid tumors," Pediatric Blood and Cancer, vol. 58, no. 3, pp. 441-447, 2012.

[48] J. A. Coppell, S. A. Brown, and D. J. Perry, "Veno-occlusive disease: cytokines, genetics, and haemostasis," Blood Reviews, vol. 17, no. 2, pp. 63-70, 2003.

[49] H. Christiansen, B. Saile, K. Neubauer-Saile et al., "Irradiation leads to susceptibility of hepatocytes to TNF- $\alpha$ mediated apoptosis," Radiotherapy and Oncology, vol. 72, no. 3, pp. 291-296, 2004.

[50] L. Zeng, Z. Yan, L. Wang, B. Du, X. Pan, and K. Xu, "Irradiation Is an early determinant of endothelial injury during hematopoietic stem cell transplantation," Transplantation Proceedings, vol. 40, no. 8, pp. 2661-2664, 2008.

[51] J. E. Levy, O. Jin, Y. Fujiwara, F. Kuo, and N. C. Andrews, “Transferrin receptor is necessary for development of erythrocytes and the nervous system," Nature Genetics, vol. 21, no. 4, pp. 396-399, 1999.

[52] A. K. Ganti, N. A. Shonka, and W. D. Haire, "Pancytopenia due to iron deficiency worsened by iron infusion: a case report," Journal of Medical Case Reports, vol. 1, article 175, 2007.

[53] A. Tichelli, A. Gratwohl, and B. Speck, "Iron deficiency anemia: diagnosis and therapy," Schweizerische Medizinische Wochenschrift, vol. 122, no. 13, pp. 461-465, 1992. 


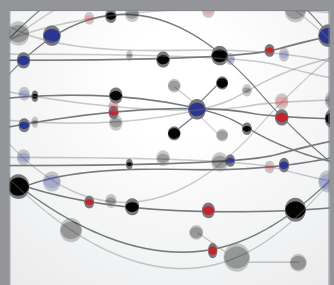

The Scientific World Journal
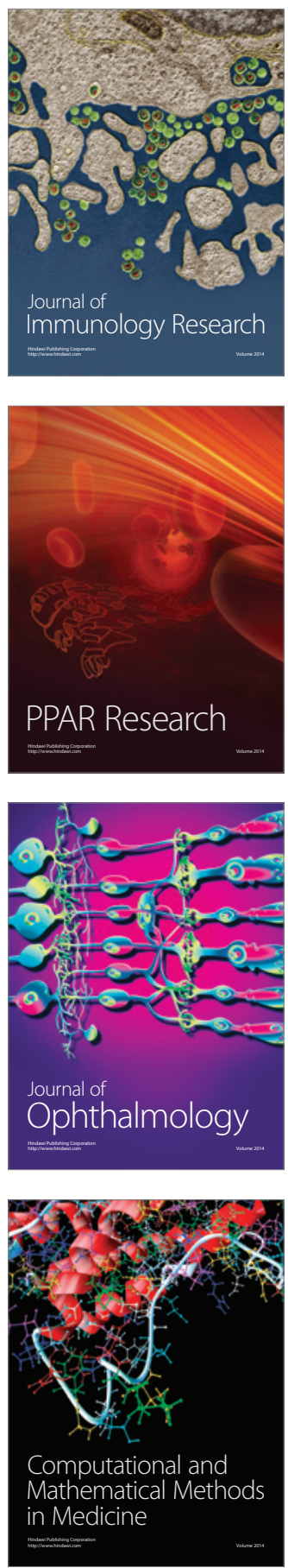

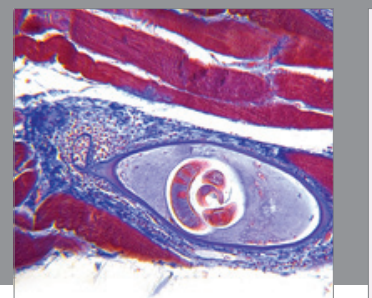

Gastroenterology

Research and Practice
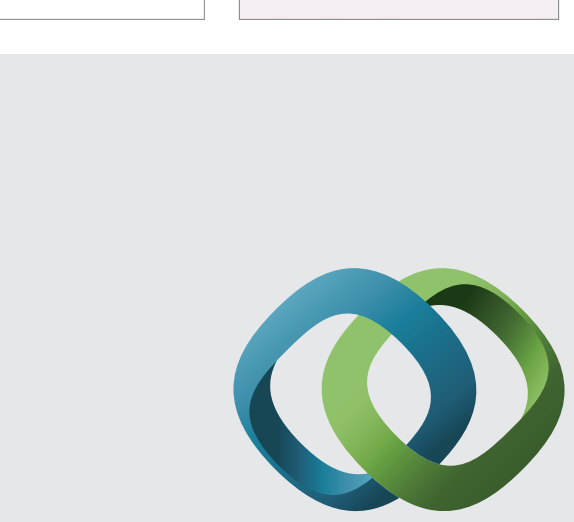

\section{Hindawi}

Submit your manuscripts at

http://www.hindawi.com
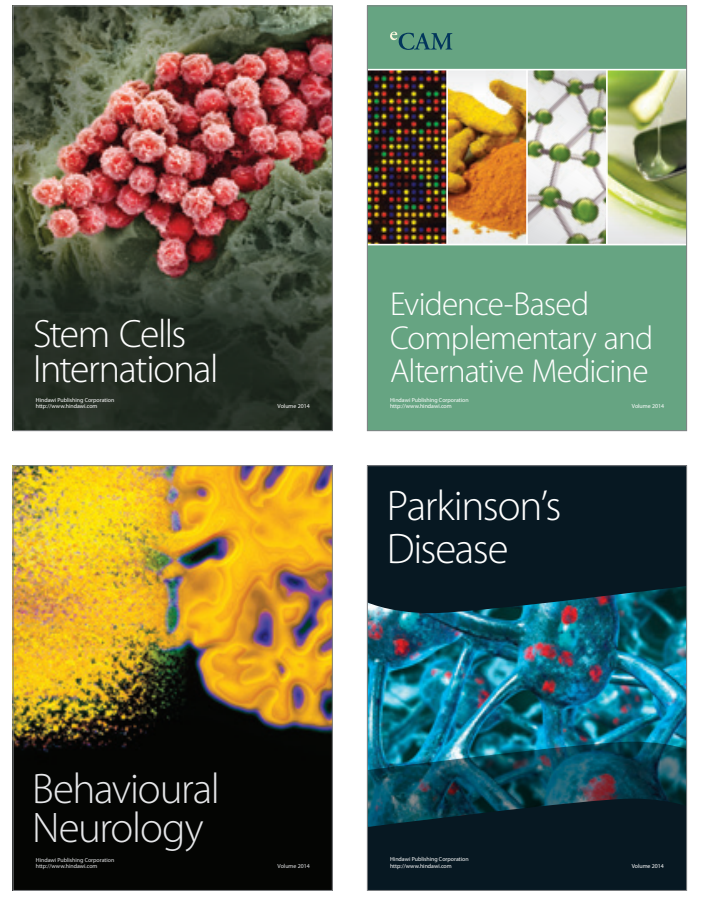
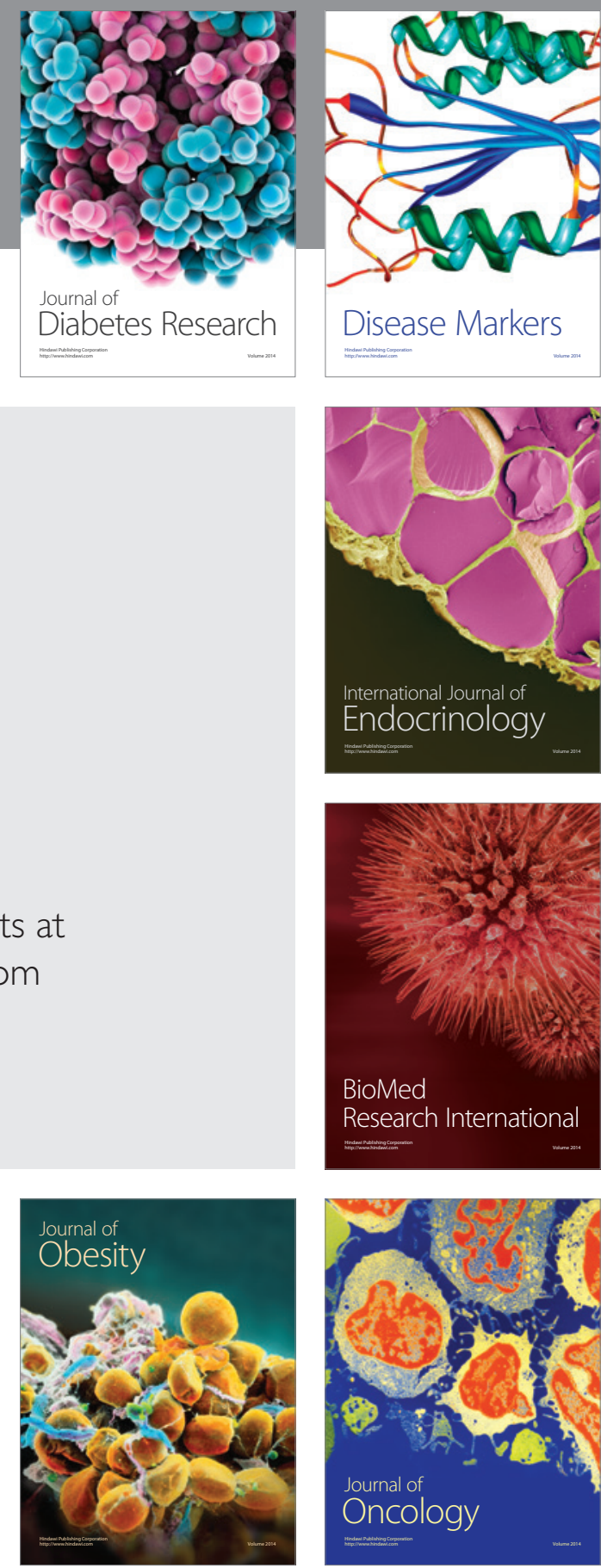

Disease Markers
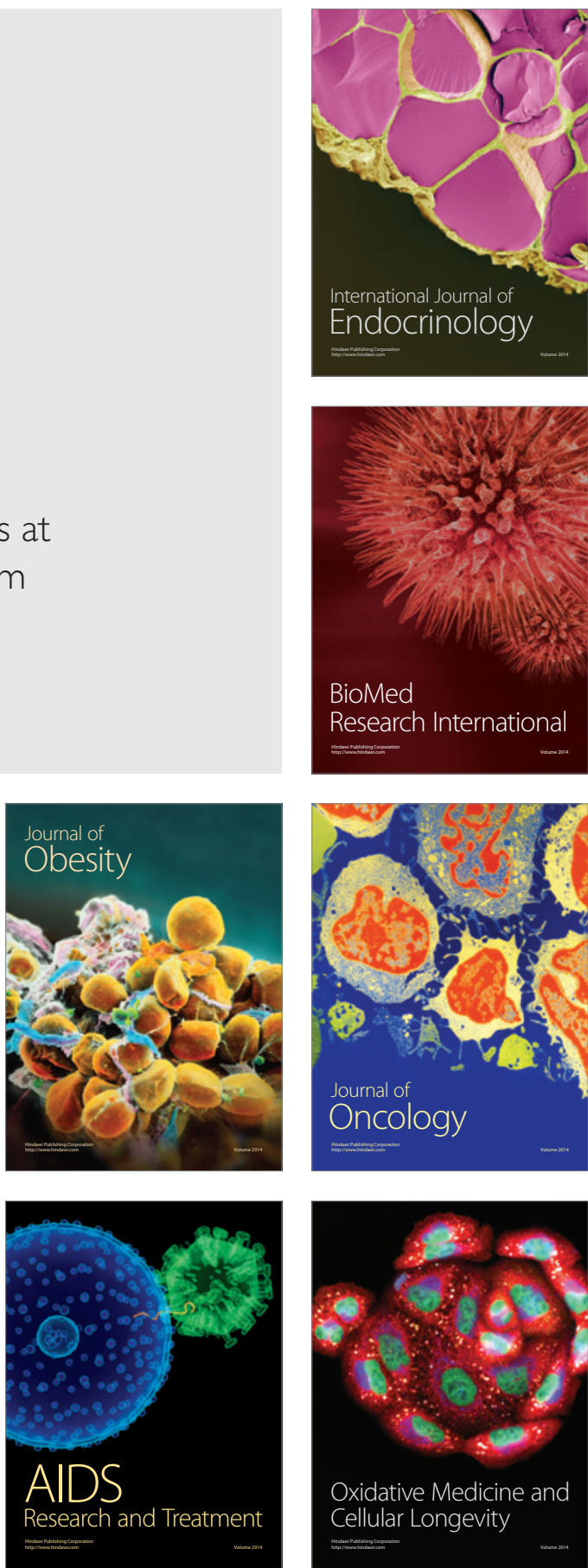